\title{
Stakeholders' Participation in School Activities in Public Secondary Schools in Los Baños, Laguna
}

\section{Roden Torrena Lacanilao \\ Los Banos National High School Batong Malake (Department of Education), Philippines. Email:roden_lacanilao@yahoo.com Tel:09293419535}

\section{Abstract}

This study was conducted to measure the stakeholders' Participation in School Activities Los Baños district, Laguna for the school year 2013-2014. It aims to compare the level of participation by school among (4) secondary public schools in Los Baños, Laguna. The data collected from the responses of the four (4) principals/OIC's, one hundred eleven (111) teachers, forty (40) barangay officials, one hundred twenty six (126) students and parents were tabulated and encoded for analysis and interpretations. The survey questionnaire was done for the survey among the (5) stakeholders which are students, principals, teachers, parents, and LGU's. It was used to determine the difference in the level of assessment and level of participation among various stakeholders in which ANOVA was used. The findings of the study revealed that the overall mean assessment of stakeholders' participation in school activity is as follows; Tuntungin Putho National High School has the highest mean level of participation. Los Baños National High School-Poblacion has the lowest levels of participation. And it was determined that there is a significant difference among stakeholders' level of participation as far as planning, decision making, information drive, and implementing were concerned.

Keywords: Stakeholders, School activities, Planning, Decision making, Information drive, School operation.

JEL Classification: I2 1 Analysis of Education.

Citation | Roden Torrena Lacanilao (2020). Stakeholders Participation in School Activities in Public Secondary Schools in Los Baños, Laguna. Asian Journal of Social Sciences and Management Studies, 7(3): 208-218.

History:

Received: 30 April 2020

Revised: 3 June 2020

Accepted: 1 July 2020

Published: 14 July 2000

Licensed: This work is licensed under a Creative Commons

Licensed: This work is
Attribution 3.0 License (cc) Er

Publisher: Asian Online Journal Publishing Group
Funding: This study received no specific financial support.

Competing Interests: The author declares that there are no conflicts of interests regarding the publication of this paper.

Transparency: The author confirms that the manuscript is an honest, accurate, and transparent account of the study was reported; that no vital features of the study have been omitted; and that any discrepancies from the study as planned have been explained.

Ethical: This study follows all ethical practices during writing.

\section{Contents}

1. The Problem and Its Background

2. Research Methodology

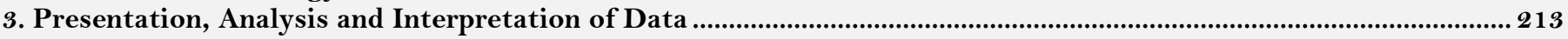

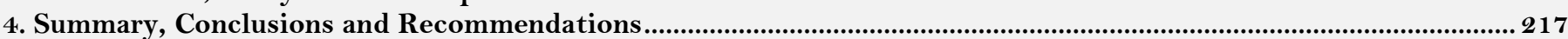

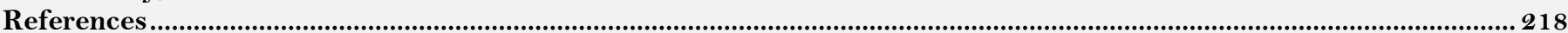




\section{Contribution of this paper to the literature}

This study has a unique contribution in terms of focusing and measuring the participation of stakeholders in identified school activities rather just participation in general, supported with national guidelines highlighting the roles and limitations of school stakeholders' involvement.

\section{The Problem and Its Background}

\subsection{Introduction}

Article XIV Section I of the Philippine Constitution declares that "The state shall protect and promote the right of all citizens to quality education at all levels and shall take appropriate steps to make such education accessible to all”. In order for the government to give education to its citizens, it provides free education by having public elementary and secondary schools but with minimal payment at state universities and colleges.

Public schools are educational institutions established and administered by the government. An act providing for the establishment and maintenance of an Integrated System of Education, Batas Pambansa Bilang 232 likewise, declares government policy to foster, at all times, a spirit of shared purposes and cooperation among the members and elements of the educational community, and between the community and other sectors of society, in the realization that only in such an atmosphere can be true goals and objectives of education be fulfilled.

Similarly, stakeholders have great involvement in the school operations of the public secondary schools. They are the individual internal or external members to an organization that has a "stake" in the success of the institutions, (edu/StrategicPlan/02.html).

The Department of Education has programs that stakeholders are involved in like: Child-Friendly School System (CFSS). Through this project, students engage more in active participation among fellow students and other school staff: teachers become more active as agents for students protection, and parents become involved in school activities; the Brigada Eskwela, demonstrates how the communities could work in teams to maintain public schools. Still another in Adopt-A-School Programs formalized by RA 8525. The program is Deped's vehicle to mobilize support from private and non-government sectors. Based on a menu of assistance packages develop by DepEd, interested companies can sponsor certain school programs/projects. The enactment act of Republic Act 9155, otherwise known as Governance of Basic Education Act of 2001, gave added impetus to the earlier efforts of the Department of Education to decentralize the governance of Basic Education at the grassroots level, however, stakeholders and the community seems to lack awareness on their roles resulting to being inactive into school's activities.

It is in this situation that the researcher became concerned in getting the stakeholders' participation in school activities of public secondary schools in Los Baños, Laguna. Results of the study can help the school administrators to assess the effectiveness of involving the stakeholders in school activities. It can also help teachers who aspire to be principal or school administrator in preparing themselves in the administration and supervision of school.

Likewise, the researcher conducted this study to find out how the public schools operates in terms of its activities, and who are the persons involved in the success of the school activities.

\subsection{Background of the Study}

The lack of awareness among stakeholders' of their roles in the school activities has been the persisting problem of the public secondary school in Los Baños District. Despite the Department of Education imposition of the Batas Pambansa Bilang 232 about their participation, their being passive in their participation to some extent affects the level of performance of the school operation.

The foregoing mandate was supplemented by the National Education Policy Act 27 of 1996 which encouraged parental participation at home and at school and to link home and school more effectively. As a result of the selected observations made by the DepEd, they generalized that children whose parents are involved in their schooling have significantly improved in their academic achievement, personality development and active in school activities. However, the ideal and expected conditions generally were not observed in the public secondary schools in the District of Los Baños. It is true that the fundamentals of the organization of Parents Teachers Associations were well attended usually in the preliminary part of the school year where parents attended the meeting for the election of PTA officers however, nothing significant follows. It is expected that every PTA shall provide mechanisms to ensure proper coordination with the members of the community, provide an avenue for assistance and support to the school for the promotion of their common interest. A very obvious instance are meeting called for Brigada Eskwela and Feeding Program, or any school activity that needs full cooperation of the parents, where less than $50 \%$ of parents come and support the program.

The students officially enrolled in the school are the important internal stakeholders of the school. Section 15 of Batas Pambansa Bilang 232, explicitly described the important role and responsibilities of the students where they need to exert their utmost development of their potentialities; uphold the academic integrity of the school; promote and maintain peace and tranquility of the school; participate actively in civic affairs, social, economic and cultural development of their community; and exercise his rights respectively.

However, in most of the observed realities, the students do not feel their sense of belongingness and the significance of this, in the future. These feelings and attitudes may affect in school activities. They do not attend to school activities, show negative attitudes to teachers and other students, and also not responsible of being students. The students need to have harmonious relationships with school staff and with other students to feel that they belong to the school.

Teachers in their employment as regular manpower of the school have big and important responsibilities as the role conveyor of knowledge to the students. Actually they still need support from other stakeholders to augment those tasks which they cannot perform alone toward the realization of the school objectives.

The school principal is the highest-ranking administrator in a public secondary. Principals are responsible for the overall operation of a school, the one who discovers that engaging the entire school staff in making decisions results in more commitment to school reform initiatives, accountable for facilitating their school's interactions with parents and others in the school community, in addition principal is liable to ensure constant supervision of the 
very young students in the school. Without effective leadership, it is not possible have "harmonious development" of each student. Only effective principals can excite the support of constituents, stakeholders, teachers, students, parents and community. The duties and responsibilities of principal are specified in Batas Pambansa Bilang 232. Section 17.

Nevertheless some of the principals do not perform their duties in the school operation and have no agreeable attitudes with school staff, and to the external stakeholders.

The Barangay as the basic political unit of the country must be visible in doing its share to every school. Section 36 of Batas Pambansa Bilang 232 defined extensively the role as well as the extent of participation of the officials of Barangay especially the counselor for education to the school located in their area.

Similarly, the officials and other key personnel in Sangguniang Barangay seemed not acquainted to their actual role. The support they draw-out to the school in their area has been infrequent, what has been started was not fully sustained.

In the light of this essential information concerning the existence of different stakeholders of the school, the researcher prompted to focus the study in the determination of the extent of participation of the stakeholders in the school activities.

\subsection{Theoretical Framework}

The essentials of a Vygotskian theory, Social Constructivist Perspective for Education for teachers: - believes that education is to develop a student's personality; that education must facilitate the development of the creative potential of students; that effective learning requires the active involvement of the learner; that teachers direct and guide the individual activity of the students but they do not dictate or force their own will on them. Authentic teaching and learning come through collaboration by adults with students; that the most valuable methods for students' teaching and learning correspond to their development and individual characteristics, and therefore, these methods cannot be uniform and that schools should provide the tools that learners need to internalize the ways of thinking central to participation in the cultural world around them.

According to Maslow, A., in his free levels of higher-order needs, there is a need for love and belongingness. The need to belong is a basic human need. Students who are accepted by teachers and classmates feel they belong to the class. Students who feel are part of the class look forward to attending class and participating in class. The sense of belongingness enhances their learning and performance.

Erikson, E., The theory of Eight Psychosocial Stage of Development is a basis for broad or complex discussion and analysis of personality and behavior, and also for understanding and for facilitating personal development - of self and others. It can help the teacher in becoming more knowledgeable of and at the same time understand the various environmental factors that affect his/her own and his/her students' personality and behavior. This theory is useful for teaching, parenting, self-awareness, managing and coaching, dealing with conflict, and generally for understanding self and others.

According to Bandura's theory as cited by Agquiz (2011) in her thesis, the idea on observation of parent's attitude on the manifestation of student's behavior can be gleaned in Bandura's theory of social learning which emphasized the importance of observing and modeling the behavior, attitudes and emotional reactions of others. It focused attention on the conditions that affect the acquisition, performance and maintenance of behavior.

According to Epstein, as cited by Calica (2011) in his theory of overlapping spheres of influence discussed six types of involvement in school, family and community partnership. The theory states that students succeed at higher levels when the internal and external model of influence interest and work together to promote students earning and development. The students learn and achieve more when the external context in which they live work together to support and enhances academic learning and success. These interactions all face under what is known as the six types of involvement or activities developed to design and implement involvement linked to the school's academic mission. Epstein six types of involvement are: (1) parenting, (2) communicating, (3) volunteering, (4) learning at home, (5) decision making, and (6) collaborating with the community.

Leader-member exchange (LMX) theory was initially called the vertical dyad linkage theory. The theory was introduced by George Graen and various colleagues in the 1970s and has been revised and refined in the years since. LMX theory emphasizes the dyadic (i.e., one-on-one) relationships between leaders and individual subordinates, instead of the traits or behaviors of leaders or situational characteristics. The theory's focus is determining the type of leader-subordinate relationships that promote effective outcomes and the factors that determine whether leaders and subordinates will be able to develop high-quality relationships. According to LMX theory, leaders do not treat all subordinates in the same manner, but establish close relationships with some (the in-group) while remaining aloof from others (the out-group). Those in the in-group enjoy relationships with the leader that is marked by trust and mutual respect. They tend to be involved in important activities and decisions. Conversely, those in the out-group are excluded from important activities and decisions.

\subsection{Conceptual Framework}

The research paradigm illustrated in Figure 1 serves as the basis for identifying the different variables considered in conducting this study. These variables are the independent variables, and the dependent variables.

Moreover, Figure 1 presents the research paradigm of the study of stakeholder's participation in school activities of public secondary schools Los Baños District School Year 2013 - 2014. Under the independent variable are the school activities such as brigada eskwela, PTA meeting, health and safety and sports fest. Dependent variables include the level of stakeholders" participation in planning, decision making, information drive and implementing.

The roles of stakeholders included in the dependent variables are the main facets of stakeholders' participation that will determine their level of involvement in the school activities. 
Independent Variables

School Activities

- Brigada Eskwela

- PTAMeeting

- Health and Safety

- Sports Fest
Dependent Variables

\section{Stakeholders'} Partcipation

\section{- Planning}

- Decision Making

- Information Drive

- Implementing

Figure-1. Research paradigm.

\subsection{Statement of the Problem}

This study aims to determine the level of participation of stakeholders in school activities of public secondary schools in Los Baños, Laguna S.Y. 2013-2014. It also aim to compare the level of participation by school among the four (4) public secondary schools in Los Baños, Laguna.

Specifically, it seeks to answer the following questions:

1. What is the assessment of stakeholders in the school activities such as brigada eskwela, PTA meeting, sports fest, and school's health and safety?

2. Is there a significant difference among the stakeholders assessment of the school activities such as Brigada Eskwela, PTA Meeting, Sports Fest and school's health and safety?

3. What is the level of stakeholder's participation in the activities of their respective school in terms of planning, decision making, information drive and implementing?

4. Is there a significant difference among stakeholder's level of participation in school activities of public secondary schools in Los Baños, Laguna in terms of planning, decision making, information drive and implementing?

\subsection{Hypotheses}

1. There is no significant difference among stakeholders' assessment of the school activities in terms of brigada eskwela, PTA meeting, sports fest, and health and safety.

2. There is no significant difference among stakeholder's level of participation, in terms of planning, decision making, information drive, and Implementing.

\subsection{Significance of the Study}

This study determined the participation of teachers, students, parents Local Government Unit and school principals, in the school activities of Public Secondary Schools, and their significance to the following:

Students. They develop and increase their motivation, achievement and potentialities for service, particularly by undergoing an education suited to their abilities, in order that they may become assets to their family and to society.

Non - academic Teaching Staff. They have the sense of belongingness to the school by involving them in the operations and cognizance in doing their duties and responsibilities.

Teachers. Their great sense of participation in the school goals and objectives, help to motivate and give strong view to students and parents in involvement in school activities, and become more responsible as a being a classroom facilitator and member of school board, because they know that their support from others.

School Principal. He/She will become more responsible as school leader is important in relation to school operations, convey plans, decision-making, and apply programs of activities which have involvement of stakeholders thereby, sharing the operating responsibility in performing the different tasks through developing in them the trust and confidence for more efficient communication systems.

School. The successful operation and wiser decision making in the school are possible through the help of stakeholders. School's vision and mission will be accomplished through the strong link between and among parents, teachers, students, Local Government Unit (Barangay Officials) and the principal.

Parents. Through giving more time to academic and non-academic schools activities of their children that can also contribute good influence on values, belief that would boost the students' self-confidence relative to fulfillment of their dreams, improve learner's performance and strengthen harmonious relationship with students, teachers, principals and their co-parents.

Local Government Unit. This study gives awareness, provides concrete concepts for the school development besides it help to them to do their duties as public servant and stakeholders of school operations.

The researcher believes that the finding of this study will help the school in its operation to become successful through the help of stakeholders, because each of them realizes their integral part to the school.

This study serves as a springboard for future principals to identify who are the stakeholders that they should approach for the improvement of the school's operation.

\subsection{Scope and Limitation of the Study}

The study focused on the stakeholders' participation in school activities of Public Secondary Schools in Los Baños, Laguna S.Y. $2013-2014$.

It seek to determine the participation of stakeholders of school such as teachers, students, parents, school's principals and Local Government Unit (Barangay Officials) in Public Secondary School namely: Los Baños 
National High School (LBNHS), Los Baños Community National High School (LBCNHS), Tuntungin Putho National High School (TPNHS) and Los Baños Integrated School (LBIS) in terms of their school activities.

This includes planning, decision making, information drive and implementing as dependent variables and also brigada eskwela, PTA meeting, health and safety and sports fest that serve as independent variables.

This study was conducted from July to October 2014 in four (4) public secondary schools in Los Baños, Laguna.

\section{Research Methodology}

This chapter presents the research methodology that plays an integral part of the study. This covers the locale of the study, research design, research population and sampling, research instrument, data gathering procedure and statistical treatment.

\subsection{Research Design}

The researcher used the descriptive method of research because it involves the description, recording, analysis and interpretation of the present nature, composition or process of the activities of the public secondary schools in Los Baños, Laguna. The focus is on the prevailing conditions or how the various stakeholders functions/behaves in the present. It also involve comparison of their level of participation whether it significantly affects school activities as far as its end results are concerned.

\subsection{Respondents of the Study}

This study was conducted in the four (4) public secondary schools in Los Baños, Laguna namely; Los Baños National High School (LBNHS) Batong Malake, Los Baños National High School (LBNHS) Poblacion, PuthoTuntungin National High School (PTNHS) and Los Baños Integrated School (LBIS).

The respondents of the study are the 126 parents, 111 teachers, 126 students, 40 Local Government Unit (Barangay Officials) and the principals in public secondary school in Los Baños, Laguna. The sample size was determined using Slovin's Formula.

\subsection{Sampling Techniques}

The tables represents the total number of stakeholders from four (4) public secondary school in Los Baños District, it was determined using Slovins Formula.

Table-1. Total population of respondents in public secondary schools in Los Baños District.

\begin{tabular}{l|c|c|c|c|c|c}
\hline School & Students & Parents & Teachers & Barangay Officials & Principal/OIC \\
\hline $\begin{array}{l}\text { Los Baños National High School } \\
\text { (LBNHS) - Batong Malake }\end{array}$ & 949 & 949 & 165 & 10 & 1 \\
\hline $\begin{array}{l}\text { Los Baños National High School } \\
\text { (LBNHS)- Poblacion }\end{array}$ & 339 & 339 & 51 & 10 & 1 \\
\hline $\begin{array}{l}\text { Tuntungin Putho National High } \\
\text { School (TPNHS) }\end{array}$ & 128 & 128 & 20 & 10 & 1 \\
\hline Los Baños Integrated School (LBIS) & 243 & 243 & 37 & 10 & 1 \\
\hline TOTAL & 1659 & 1659 & 273 & 40 & 4 \\
\hline
\end{tabular}

Table 1 shows the total population of respondents in public secondary schools in in Los Baños district. There are four (4) high schools in the district namely, Los Baños National High School (LBNHS) - Batong Malake, Los Baños National High School (LBNHS) - Poblacion, Tuntungin Putho National High School (TPNHS), and Los Baños Integrated School (LBIS). The respondents from each school are consist of students, parents, teachers, barangay officials, and principals. With regards to the table, the Los Baños National High School- Batong Malake has the largest population of respondents because it is situated in a highly densed populated area.

Table-2. Sample size of respodents in public secondary school in Los Baños District.

\begin{tabular}{|c|c|c|c|c|c|c|c|c|}
\hline \multirow[t]{2}{*}{ School } & \multicolumn{2}{|c|}{ Students } & \multicolumn{2}{|c|}{ Parents } & \multicolumn{2}{|c|}{ Teachers } & \multirow{2}{*}{$\begin{array}{c}\text { Barangay } \\
\text { Officials }\end{array}$} & \multirow[t]{2}{*}{ Principal/OIC } \\
\hline & $\begin{array}{c}\text { Sample } \\
\text { Size } \\
\end{array}$ & $40 \%$ & $\begin{array}{c}\text { Sample } \\
\text { Size }\end{array}$ & $40 \%$ & $\begin{array}{c}\text { Sample } \\
\text { Size }\end{array}$ & $40 \%$ & & \\
\hline LBNHS - Batong Malake & 184 & 74 & 184 & 74 & 165 & 66 & 10 & 1 \\
\hline LBNHS - Poblacion & 66 & 26 & 66 & 26 & 51 & 20 & 10 & 1 \\
\hline TPNHS & 25 & 10 & 25 & 10 & 20 & 8 & 10 & 1 \\
\hline LBIS & 47 & 18 & 47 & 18 & 37 & 15 & 10 & 1 \\
\hline TOTAL & 322 & 128 & 322 & 128 & 273 & 109 & 40 & 4 \\
\hline
\end{tabular}

The Table 2 shows the sample size of respondents in public secondary schools in Los Baños district. The sample size was obtained applying stratified random sampling, from which sample size was derived from each school using their total population as a reference. Los Baños National High School-Batong Malake got the higest sample size of respondents since it had the largest number of population among the four (4) schools.

\subsection{Research Instrument}

The researcher used a self-made questionnaire that was submitted to his adviser and other experts for corrections and validations.

The questionnaire was divided into two parts: part 1 contains the assessment of stakeholders in school activities such as Brigada Eskwela, PTA meeting, Sports Fest and Health and Safety, part 2 on the otherhand contains the level of participation of stakeholders in schools activities in terms of planning, decision making, information drive and implementing. For the first part, on the assessment of school activities, a scale of 1 to 100 
was used, the higher the value indicates better assessment, while on the second part, a 1 to 5 number scale was used wherein 5 is very highly participative and 1 is non participative.

\subsection{Research Procedure}

A letter of request for approval to conduct the study was handed personally by the researcher to the district supervisor, principals and also to barangay officials and parents in Los Baños, Laguna.

The researcher personally administered the questionnaire among the principals, teachers, students, parents and barangay officials. Data were tallied, tabulated, analyzed and interpreted.

\subsection{Statistical Treatment of Data}

Mean and Standard deviation were used to measure the mean assessment of stakeholders in the school activities and level of participation in terms of planning, decision making. Information drive, and implementing.

ANOVA was employed to determine the level of stakeholders' assessment of school activities and level of participation in terms of planning, decision making, information drive, and implementing.

\section{Presentation, Analysis and Interpretation of Data}

This chapter presents the data gathered from the study and their corresponding analysis and interpretation.

The study was conducted to determine the stakeholders' participation in school activities in public secondary schools in Los Baños Laguna school year 2013-2014.

The presentation of findings is based on the sequence of the statement of the problem such as to find the assessment of stakeholders in the school activities such as brigada eskwela, PTA meeting, sports fest and school's health and safety, level of stakeholders' participation in activities of their respective school in terms of plannin, decision making, information drive, and implementating and to determine the difference between the mean of stakeholders' participation in school activities.

The level of stakeholders' assessment in school activities in terms of Brigada Eskwela is reflected on Table 3. The principals have the highest mean on the assessment of Brigada Eskwela with 4.25, followed by teachers with 3.96. it showed that all stakeholders reflect a high level of assessment in Brigada Eskwela and the lowest mean assessment were the LGUs with 3.29, described as Good. The overall assessment of 3.87, described as Very Good, means that almost all materials were prepared, most of the invited stakeholders participated, classrooms and chairs were fixed and school buildings were painted in the Bridada Eskwela.

Table-3. Assessment of stakeholders in school activities in terms of Brigada Eskwela

\begin{tabular}{|c|c|c|c|c|c|}
\hline Stakeholders' Participation & Stakeholders & $\mathbf{N}$ & Mean & Standard Deviation & Descriptive Interpretation \\
\hline \multirow{5}{*}{ Brigada Eskwela } & Students & 126 & 3.94 & 0.862 & Very Good \\
\hline & Parents & 126 & 3.89 & 0.858 & Very Good \\
\hline & Teachers & 111 & 3.96 & 0.704 & Very Good \\
\hline & LGU & 40 & 3.29 & 0.860 & Good \\
\hline & Principal & 4 & 4.25 & 0.000 & Excellent \\
\hline Overall Mean & & & 3.87 & & Very Good \\
\hline
\end{tabular}

Since the principals were considered the head of the school, they understand clearly the importance of Brigada Eskwela more than anyone and it reflects to their assessment, giving Brigada Eskwela an excellent rating. However, the lowest assessment was given by the LGUs. This implies that LGUs have little awareness of the activities regarding Brigada Eskwela.

Table-4. Assessment of stakeholders in school activities in terms of PTA meeting.

\begin{tabular}{l|c|c|c|c|c}
\hline Stakeholders' Participation & Stakeholders & $\mathbf{N}$ & Mean & Standard Deviation & Descriptive Interpretation \\
\hline \multirow{3}{*}{ PTA Meeting } & Students & 126 & 4.15 & 0.892 & Very Good \\
\cline { 2 - 6 } & Parents & 126 & 3.87 & 0.872 & Very Good \\
\cline { 2 - 6 } & Teachers & 111 & 3.85 & 0.789 & Very Good \\
\cline { 2 - 6 } & LGU & 40 & 3.21 & 0.738 & Good \\
\cline { 2 - 6 } & Principal & 4 & 4.15 & 0.000 & Very Good \\
\hline Overall Mean & \multicolumn{7}{|c|}{3.85} & Very Good \\
\hline Note: 4.21 -5.00 Excellent (E); 3.4.1-4.20 Very Good (VG); 2.61-3.40 Good (G); $1.81-2.60$ Fair (F); 1.00-1.80 Poor (P).
\end{tabular}

The mean assessment of stakeholders in school activities in terms of PTA meeting is shown in Table 4 . It shows that principals and students have the same highest mean of 4.15, LGU had the lowest mean value of 3.21 with regards to PTA meeting. LGU seems not to be very satisfied in terms of the turnouts of PTA meeting.

All of the stakeholders gave an overall rating of Very Good in terms of PTA meeting. LGUs on the other hand rated it only Good. An overall rating of 3.85 described as Very Good implies that the school provides many opportunities for parents to interact and get to know each other building a strong ties with the school.

Table-5. Assessment of stakeholders in school activities in terms of sports fest.

\begin{tabular}{l|c|c|c|c|c}
\hline Stakeholders' Participation & Stakeholders & N & Mean & Standard Deviation & Descriptive Interpretation \\
\hline \multirow{3}{*}{ Sports Fest } & Students & 126 & 4.33 & 0.761 & Excellent \\
\cline { 2 - 6 } & Parents & 126 & 4.16 & 0.827 & Very Good \\
\cline { 2 - 6 } & Teachers & 111 & 3.97 & 0.839 & Very Good \\
\cline { 2 - 6 } & LGU & 40 & 3.33 & 0.779 & Good \\
\cline { 2 - 6 } & Principal & 4 & 4.31 & 0.000 & Excellent \\
\hline Overall Mean & \multicolumn{2}{|c|}{4.02} & Very Good \\
\hline Note: 4.21 -5.00 Excellent (E); 3.41-4.20 Very Good (VG); & $2.61-3.40$ Good (G); 1.81-2.60 Fair (F); 1.00-1.80 Poor (P).
\end{tabular}


Table 5 represents the assessment of stakeholders on sports fest. Both students and principals gave it a grade of excellent with the mean of 4.33 and 4.31 respectively. This was followed by parents with 4.16 and teachers with 3.97 both giving a grade of very good. LGU had the lowest mean of 3.33 and rated as good. An overall assessment of 4.02, described as very good means that sports fest has influenced many students to engage in sports activities.

Students, teachers and principals were the most involved in terms of sports fest activities. That is why they were able to give a high assessment.

Table-6. Assessment of stakeholders in school activities in terms of health and safety.

\begin{tabular}{l|c|c|c|c|c}
\hline Stakeholders' Participation & Stakeholders & $\mathbf{N}$ & Mean & Standard Deiation & Descriptive Interpretation \\
\hline \multirow{3}{*}{ Health and Safety } & Students & 126 & 4.18 & 0.942 & Very Good \\
\cline { 2 - 6 } & Parents & 126 & 3.92 & 0.927 & Very Good \\
\cline { 2 - 6 } & Teachers & 111 & 3.76 & 0.820 & Very Good \\
\cline { 2 - 6 } & LGU & 40 & 3.09 & 0.746 & Good \\
\cline { 2 - 6 } & Principal & 4 & 4.44 & 0.000 & Excellent \\
\hline Overall Mean & \multicolumn{2}{|c|}{3.88} & Very Good \\
\hline Note: 4.21 -5.00 Excellent (E); 3.41-4.20 Very Good (VG); 2.61-3.40 Good (G); 1.81-2.60 Fair (F);
\end{tabular}

Assessment on health and safety is shown on Table 6. Principals gave the highest assessment with the mean of 4.44 which means excellent. Students, parents and teachers have means of 4.18, 3.92 and 3.76 respectively which is very good. Again LGU only managed to come up with an assessment of Good.

The average mean assessment given by stakeholders was 3.88 which means that all stakeholders understand their roles and took part in ensuring student's health and safety. The result revealed that health and safety was one of the top priorities of each school.

Table-7. Assessment of stakeholders on different school activities.

\begin{tabular}{|c|c|c|c|}
\hline Activity & Mean & Rank & Remarks \\
\hline Brigada Eskwela & 3.67 & 4 & Very Good \\
\hline PTA Meeting & 3.84 & 3 & Very Good \\
\hline Sports Fest & 4.01 & 1 & Very Good \\
\hline Health and Safety & 3.87 & 2 & Very Good \\
\hline Overall Mean & 3.85 & \multicolumn{2}{|c|}{ Extent of assessment on different activities is high } \\
\hline
\end{tabular}

The overall assessment of stakeholders in the district of Los Baños on the different school activities is shown in Table 7. Sport fest has the highest mean of 4.01, next is health and safety with 3.87 , followed by PTA meeting with 3.84 and Brigada Eskwela with 3.67.

From the given data, all activities were assessed and given the rating of Very Good by the stakeholders. This simply means that all activities were conducted and participated well by the different stakeholders which reflects their high awareness and support to the school activities.

The data presented in Table 8 , shows that there is a high significant difference among the stakeholders' assessment in school activities such as Brigada Eskwela, PTA meeting, Sport Fest and Health and Safety $(\operatorname{sig}=0.000)$. In Brigada Eskwela LGU is significantly different from the assessment of the other stakeholders.

\begin{tabular}{|c|c|c|c|c|c|c|c|}
\hline Activities & Students & Parents & Teachers & LGU & Head & F-Value & Sig \\
\hline Brigada Eskwela & $4.00 \mathrm{a}$ & $3.87 \mathrm{ab}$ & $3.88 \mathrm{ab}$ & $3.29 \mathrm{c}$ & $4.25 \mathrm{ab}$ & 11.57 & 0.000 \\
\hline PTA Meeting & $4.04 a$ & $3.95 \mathrm{ad}$ & $3.74 \mathrm{~b}$ & $3.21 \mathrm{c}$ & $4.15 \mathrm{ad}$ & 13.33 & 0.000 \\
\hline Sports Fest & $4.20 \mathrm{a}$ & 4.05be & 3.89ce & $3.33 \mathrm{~d}$ & $4.31 \mathrm{ae}$ & 16.64 & 0.000 \\
\hline Health and Safety & $4.04 a$ & $3.95 \mathrm{a}$ & $3.96 \mathrm{a}$ & $3.08 \mathrm{~b}$ & $4.44 a$ & 16.04 & 0.000 \\
\hline
\end{tabular}

In PTA meeting, the assessment of LGU which is the lowest, is significantly different with those of the other stakeholders. Likewise the assessment of teachers as well as the students are also significantly different, however, the assessment of parents and principals, which are all Very Good are not significantly different.

Table-9. The mean level of stakeholders' participation in school activities in terms of planning.

\begin{tabular}{|c|c|c|c|c|c|}
\hline Stakeholders' Participation & Stakeholders & $\mathbf{N}$ & Mean & Standard Deviation & Descriptive Interpretation \\
\hline \multirow{5}{*}{ Planning } & Students & 126 & 4.01 & 1.209 & Highly Participative \\
\hline & Parents & 126 & 3.73 & 0.985 & Highly Participative \\
\hline & Teachers & 111 & 3.85 & 0.851 & Highly Participative \\
\hline & LGU & 40 & 3.34 & 0.764 & Moderately Participative \\
\hline & Principal & 4 & 4.58 & 0.000 & Very Highly Participative \\
\hline Overall Mean & & & 3.90 & & Highly Participative \\
\hline
\end{tabular}

Note: 4.2 1-5.00 Very Highly Participative (VHP); 3.41-4.20 $\quad$ Highly Participative (HP); 2.61-3.4 Moderately Participative (MP); 1.81-2.60Low Participative (LP); 1.00-1.80 Non-Participative (NP).

Table 9 shows the mean value of their participation in terms of planning school activities. The principal as the head of the school took the highest level of participation with mean value of 4.58 which is very highly participative. Next are students with mean of 4.01, teachers with 3.85 and parents with 3.73 all three being highly participative. The least participation was the LGUs with 3.34 which is moderately participative.

The principal is the most active in terms of planning of school activities. Reason for this may account to his/her duty as the main initiator and planner of the school activities. 
Overall, the stakeholders were Highly Participative in terms of planning, which means that they attend to planning meetings conducted by the school and they are also involved in the conceptualizing of every school activity.

Table 10 shows stakeholders' participation in decision making. The principals were the highest mean level of participation with 4.25 which is described as very highly participative, followed by students and parents, both with 4.02, then teachers with 3.87 all three are highly participative and the lowest mean level of participation were the LGUs with 3.36, which is moderately participative.

Table-10. The mean level of stakeholders' participation in school activities in terms of decision making.

\begin{tabular}{|c|c|c|c|c|c|}
\hline $\begin{array}{l}\text { Stakeholders' } \\
\text { Participation }\end{array}$ & Stakeholders & $\mathbf{N}$ & Mean & $\begin{array}{c}\text { Standard } \\
\text { Deviation }\end{array}$ & Descriptive Interpretation \\
\hline \multirow{5}{*}{ Decision Making } & Students & 126 & 4.02 & 1.02 & Highly Participative \\
\hline & Parents & 126 & 4.02 & 0.951 & Highly Participative \\
\hline & Teachers & 111 & 3.87 & 1.05 & Highly Participative \\
\hline & LGU & 40 & 3.36 & 0.860 & Moderately Participative \\
\hline & Principal & 4 & 4.25 & 0.000 & Very Highly Participative \\
\hline Overall Mean & & & 3.90 & & Highly Participative \\
\hline
\end{tabular}

1.81-2.60Low Participative (LP) ; 1.00-1.80 Non-Participative (NP).

The LGU's are the least involved in terms of decision making, a duty of a barangay official is very tasking, the school is not their only concern, the whole community is. That is why among the stakeholders they fair low in terms of participation in decision making.

However, the overall mean level of participation suggests high participation which indicates that most of the stakeholders were part of the school's decision making body. They contribute substantial ideas and information that can be a big indicator in the success of school activities.

Principals were the one who's exposed to many aspects of decision making. Circumstances may arise that needs immediate response which he/she can provide.

Table-11. The mean level of stakeholders' participation in school activities in terms of information drive.

\begin{tabular}{|c|c|c|c|c|c|}
\hline Stakeholders' Participation & Stakeholders & $\mathbf{N}$ & Mean & Standard Deviation & Descriptive Interpretation \\
\hline \multirow{5}{*}{ Information Drive } & Students & 126 & 4.21 & 0.95 & Very Highly Participative \\
\hline & Parents & 126 & 3.69 & 1.07 & Highly Participative \\
\hline & Teachers & 111 & 4.04 & 0.787 & Highly Participative \\
\hline & LGU & 40 & 3.58 & 0.796 & Highly Participative \\
\hline & Principal & 4 & 4.34 & 0.000 & Very Highly Participative \\
\hline Overall Mean & & & 3.97 & & Highly Participative \\
\hline
\end{tabular}

Note: 4.2 1-5.00 Very Highly Participative (VHP); 3.41-4.20 Highly Participative (HP); 2.61-3.4 Moderately Participative (MP);

1.81-2.60Low Participative (LP); 1.00-1.80 Non-Participative (NP).

Table 11 shows the mean level of participation in terms of information drive. The highest mean level of participation were the principals with 4.34, very highly participative. Same with students with 4.21, followed by teachers with 4.04, parents with 3.69 and LGU with 3.58, all with high participation. It make sense that the principals were the most involved in information drive because he/she is the main source of information and the students as the dissemination of it that act as a bridge to their parents and community.

The overall mean of 3.97, described as highly participative, revealed that there is a strong network of communication between the school and the stakeholders. Dissemination of information was fast and effective which is very important to ensure maximum participation of stakeholders in school activities.

Table-12. The mean level of stakeholders' participation in school activities in terms of implementing.

\begin{tabular}{l|c|c|c|c|l}
\multicolumn{6}{c}{ Table-12. The mean level of stakeholder' participation in school activities in terms of implementing. } \\
\hline Stakeholders' Participation & Stakeholders & $\mathbf{N}$ & Mean & Standard Deviation & Descriptive Interpretation \\
\hline \multirow{4}{*}{ Implementing } & Students & 126 & 4.15 & 0.994 & Highly Participative \\
\cline { 2 - 6 } & Parents & 126 & 3.70 & 1.03 & Highly Participative \\
\cline { 2 - 6 } & Teachers & 111 & 4.10 & 0.804 & Highly Participative \\
\cline { 2 - 6 } & LGU & 40 & 3.56 & 0.831 & Highly Participative \\
\cline { 2 - 6 } & Principal & 4 & 4.59 & 0.000 & Very Highly Participative \\
\hline \multicolumn{7}{|c|}{4.02} & Highly Participative \\
\hline
\end{tabular}

Note: 4.21-5.00 Very Highly Participative (VHP); 3.41-4.20 Highly Participative (HP); 2.61-3.4 Moderately Participative (MP);

1.81-2.60Low Participative (LP); 1.00-1.80 Non-Participative (NP).

The mean level of participation in terms of implementing is presented in Table 12. It shows that the principal had the highest mean level of participation with 4.59, described as very highly participative, followed by students with 4.15 , teachers with 4.10 , parents with 3.70 and LGUs with 3.56 , all are highly participative. All stakeholders reflected that they have high level of participation in terms of the implementation of school activities.

The principal is the immediate and major implementing body of the school rules, guidelines, decisions and school activities must be consulted first to the principal before being implemented.

Overall mean value of 4.02, described as Highly Participative, only shows that every stakeholder were part of the implementation of every school program. All must have shared purposes and responsibilities on the implementation of school activities.

Table 13 represents the mean level of stakeholders' participation in school activities in terms of planning. TPNHS with the mean of 4.01 was the highest, it means highly participative as well as the other schools. LBIS got 3.96 while LBNHS-Poblacion and LBNHS-Batong Malake had 3.82. The result shows high participation of stakeholders in terms of getting involved in the planning of school activities. 
Table-13. Mean level of stakeholders' participation in the school activities of their respective schools in terms of planning.

\begin{tabular}{l|c|c|c|l}
\hline Schools & N & Mean & Standard Deviation & Descriptive Interpretation \\
\hline LBIS & 62 & 3.96 & 0.719 & Highly Participative \\
\hline LBNHS-Poblacion & 83 & 3.82 & 0.86 & Highly Participative \\
\hline LBNHS-Batong Malake & 217 & 3.82 & 0.875 & Highly Participative \\
\hline TPNHS & 45 & 4.01 & .594 & Highly Participative \\
\hline Overall Mean & & 3.90 & & Highly Participative
\end{tabular}

Note: 4.21-5.00 Very Highly Participative (VHP); 3.41-4.20 Highly Participative (HP); 2.61-3.4 Moderately Participative (MP);

1.81-2.60Low Participative (LP); 1.00-1.80 Non-Participative (NP).

Table-14. Mean level of stakeholders' participation in the school activities of their respective schools in terms of decision making.

\begin{tabular}{l|c|c|c|l}
\hline Schools & N & Mean & Standard Deviation & Descriptive Interpretation \\
\hline LBIS & 62 & 3.94 & 0.713 & Highly Participative \\
\hline LBNHS-Poblacion & 83 & 3.83 & 0.946 & Highly Participative \\
\hline LBNHS-Batong Malake & 217 & 3.81 & 0.749 & Highly Participative \\
\hline TPNHS & 45 & 4.03 & 0.645 & Highly Participative \\
\hline Overall Mean & \multicolumn{3}{|c|}{3.90} & Highly Participative \\
\hline Note: $4.91-5.00$
\end{tabular}

Note: 4.21-5.00 Very Highly Participative (VHP); 3.41-4.20 Highly Participative (HP); 2.61-3.4 Moderately Participative (MP);

1.81-2.60Low Participative (LP); 1.00-1.80 Non-Participative (NP).

The mean level of stakeholders' participation in school activities in terms of decision making is shown in Table 14. TPNHS ranked first with the mean level of 4.03 which is highly participative as well as LBIS with 3.94, LBNHS-Poblacion with 3.83 and LBNHS-Batong Malake with 3.81. The data shows that stakeholders from four (4) public secondary schools have high participation in making decisions regarding school activities.

Table-15. Mean level of stakeholders' participation in the school activities of their respective schools in terms of information drive.

\begin{tabular}{|c|c|c|c|c|}
\hline Schools & $\mathbf{N}$ & Mean & Standard Deviation & Descriptive Interpretation \\
\hline LBIS & 62 & 3.88 & 0.697 & Highly Participative \\
\hline LBNHS-Poblacion & 83 & 3.93 & 0.721 & Highly Participative \\
\hline LBNHS-Batong Malake & 217 & 3.95 & 0.772 & Highly Participative \\
\hline TPNHS & 45 & 4.11 & 0.634 & Highly Participative \\
\hline Overall Mean & & 3.97 & & Highly Participative \\
\hline
\end{tabular}

Table 15 shows the mean level of participation of stakeholders in information drive. The four (4) schools have been highly participative. TPNHS had the highest mean level of participation with 4.11 , followed by LBNHSBatong Malake with 3.95, LBNHS-Poblacion with 3.93 and LBIS had the lowest mean of 3.88. This means that all four (4) public secondary schools were highly participative in the dissemination of information involving school activities.

Table-16. Mean level of stakeholders' participation in the school activities of their respective schools in terms of implementation.

\begin{tabular}{l|c|c|c|l}
\hline Schools & N & Mean & Standard Deviation & Descriptive Interpretation \\
\hline LBIS & 62 & 4.17 & 0.693 & Highly Participative \\
\hline LBNHS-Poblacion & 83 & 3.87 & 0.639 & Highly Participative \\
\hline LBNHS-Batong Malake & 217 & 4.00 & 0.803 & Highly Participative \\
\hline TPNHS & 45 & 4.08 & 0.771 & Highly Participative \\
\hline Overall Mean & 407 & 4.03 & Highly Participative \\
\hline Note: $4.91-5.00 \quad$ Very Highly Particiative (VHP)
\end{tabular}

Highly Participative (HP); 2.61-3.4 Moderately Participative (MP);

1.81-2.60Low Participative (LP) ; 1.00-1.80 Non-Participative (NP).

Table 16 represents stakeholders' participation on the implementation of school activities. The data shows that LBIS had the highest mean level of participation with 4.17, TPNHS with 4.08, LBNHS-Batong Malake with 4.00 and LBNHS-Poblacion with 3.87. Again the four (4) public secondary schools exhibit high participation, this time in terms of the processes and guidelines of implementing school activities.

\begin{tabular}{l|c|c|l}
\multicolumn{4}{c}{ Table-17. Involvement of stakeholders on different school activities. } \\
\hline Activity & Mean & Rank & Remarks \\
\hline Planning & 3.90 & 3.5 & Highly Participative \\
\hline Decision Making & 3.90 & 3.5 & Highly Participative \\
\hline Information Drive & 3.97 & 2 & Highly Participative \\
\hline Implementing & 4.03 & 1 & Highly Participative \\
\hline Overall Mean & 3.95 & Extent of involvement on different activities is high \\
\hline $\begin{array}{l}\text { Note: 4.21-5.00 Very Highly Participative (VHP); 3.41-4.20 Highly Participative (HP); 2.61-3.4 Moderately Participative (MP); } \\
\text { 1.81-2.60Low Participative (LP); 1.00-1.80 Non-Participative (NP). }\end{array}$
\end{tabular}

Table 17 shows that stakeholders were more participative in implementing of school activities with the mean of 4.03. Second is information drive with 3.97 and 3.90 for planning and decision making.

Stakeholders were least involved in planning and decision making, implementing and information drive on the other hand got the better participation. With the overall mean of 3.95 the extent of involvement on the school activities is high. 
Table-18. Test of difference on the participation of stakeholders on different schools activities

\begin{tabular}{l|c|c|c|c|c|c|c}
\hline Activities & Students & Parents & Teachers & LGU & Head & F-Value & Sig \\
\hline Planning & $3.7 \mathrm{a}$ & $3.79 \mathrm{a}$ & $3.72 \mathrm{a}$ & $3.34 \mathrm{a}$ & $4.58 \mathrm{~b}$ & 2.874 & 0.023 \\
\hline Decision Making & $3.73 \mathrm{a}$ & $4.05 \mathrm{bd}$ & $3.69 \mathrm{ac}$ & $3.36 \mathrm{a}$ & $4.25 \mathrm{~d}$ & 7.071 & 0.000 \\
\hline Information Drive & $4.01 \mathrm{a}$ & $3.82 \mathrm{ac}$ & $4.03 \mathrm{a}$ & $3.56 \mathrm{bc}$ & $4.34 \mathrm{a}$ & 2.741 & 0.028 \\
\hline Implementation & $3.90 \mathrm{a}$ & $3.81 \mathrm{a}$ & $4.09 \mathrm{a}$ & $3.56 \mathrm{~b}$ & $3.56 \mathrm{~b}$ & 3.078 & 0.016 \\
\hline
\end{tabular}

Table 18 specifically shows that the computed values were found to be significant. This means that there is significant difference among the stakeholders participation in terms of planning, decision making, information drive and implementing.

In Planning, the principal's level of participation is significantly different with the other stakeholders. In terms of Decision Making, the participations of parents and principals were significantly different with the others. The LGU in terms of Information Drive, was significantly different with the other stakeholders and in terms of implementation of school activities, the table shows that the level of participation by the principals and LGU's were significantly different with the participation of other stakeholders. Stakeholders differ in their level of participation this may be accounted on their awareness of the activities happening in the school, internal stakeholders seem to be more aware and committed to the school activities.

A study made by Masarap (2013) which indicate findings that principals are the one who had the greatest involvement in the school operations and activities was supported this study. On the other hand, Masarap's study revealed that parents are the least involved in terms of school activities, this is quite different, relative to the results and findings of this study which showed that the LGU's were the least involved.

Structures and characteristics of stakeholders varies from place to places, and this explains the difference of findings between the two, at least on the part revealing who were the least involved.

\section{Summary, Conclusions and Recommendations}

This chapter presents the summary of findings, conclusions and recommendations of the study.

\subsection{Summary}

The study showed that as far as the assessment in school activities was concerned, among (4) secondary schools in the district of Los Baños, Tuntungin Putho National High School have the highest mean assessment, and the lowest mean assessment was Los Baños National High School-Poblacion.

The principals have the highest mean assessment in school activities while LGU gave the lowest mean assessment.

All of (4) High schools in Los Baños District are highly participative in terms of the school activities, Tuntungin Putho National High School have the topmost mean level of participations, and Los Baños National High School-Batong Malake was in the bottom mean level of participation.

In terms of participation in school activities, all (5) stakeholders were highly participative, principals had the highest mean level of participation, and LGU was in the bottom mean level of participation.

There was significant difference of stakeholders' assessment as far as school activities was concerned. The mean assessment of stakeholders in school activities was reflected that the principals had the highest mean assessment of the school activities and the lowest mean assessment were the LGU's.

There were also significant differences among students, parents, teachers, LGU's, and principals in terms of their participation in the different school activities. The highest mean levels of participation were the principals and the lowest levels of participation were the LGU's.

There was significant difference among stakeholders assessment among (4) High Schools as far as school activities are concerned.

There is a significant difference among the (4) High Schools in the municipality of Los Baños , in terms of stakeholders participation in school activities.

\subsection{Conclusion}

The null hypothesis stating that there is no significant difference among stakeholders' mean assessment of school activities such as brigada eskwela, PTA meeting, sports fest, and health and safety was rejected, there were significant differences among stakeholders' mean assessment of school activities such as brigada Eskwela, pta meeting, sports fest, and health and safety.

The null hypothesis stating that there is no significant difference among stakeholders' level of participation in terms of planning, decision making, information drive, and health and safety was rejected, there were significant differences among stakeholders' level of participation in school activities in terms of planning, decision making, information drive, and implementing.

A school is composed of stakeholders, each with different role and responsibility, thus their participation also varies. The principal acts as the leader, and the most involved in the implementation of the school activities, on the other hand LGU's are focus on a much broader issue including facing the problems of the barangay, this explains why they were the least involved in activities of the school.

\subsection{Recommendations}

Relative to the results and findings, the principals must have a good relationship with every stakeholder, to be able to build a strong network of communication which is necessary on the success of school activities. A spirit of acceptance must be felt by stakeholders, making them part of every school activity, promoting shared purposes and responsibilities. 
Teachers may inform students and parents about their duties and responsibilities as stakeholders of the school. Constant communication with parents is very important. They must be the role model of their students in showing their commitment cooperation to the school's activities.

Students may have a sense of responsibility, being aware of their role which play a big part on the success of school activities. They are whom who provide the main structure of every school activity and which the success of it greatly depends on them.

Parents may ask their children regarding on the activities happening on the school, it will be good to pay a visit once in a while to be updated of the school's programs and activities. Also provide the school with necessary information to be used as reference if the needs arise wherein their participation is necessary.

Local government Unit (Barangay Officials) may extend their help and support to school activities. They must have a constant line of communication with the school, giving the school the assurance of their help and cooperation on every school activity.

\section{References}

Agquiz, P. L. (2011). The impact of parents' role among the first year students' behavior at national high school in Tanauan City West: A basic for an action plan. Calamba City: Laguna College of Business and Arts.

Calica, C. G. A. (2011). Parent's participation in the education of their children and its impact on academic performance and behavioral development a basis for an action plan. Calamba City: Laguna College of Business and Arts.

Masarap, J. W. (2013). Stakeholders' participation in school operations of lowland public elementary schools in bay district, Laguna SY 2010-2011. Los Baños, Laguna: Laguna State Polytechnic University-Los Baños Campus. 